\title{
Recovery of Bacteria from Damages Induced by Heat
}

\author{
By P. MUKHERJEE AND S. B. BHATTACHARJEE \\ Biophysics Division, Saha Institute of Nuclear Physics, Calcutta 37, India
}

(Accepted for publication 27 October 1969)

\section{SUMMARY}

When Escherichia coli B was heated at $52^{\circ}$ and subsequently incubated at $20^{\circ}$ or at $37^{\circ}$ in phosphate buffer, there was an increase in the number of viable organisms. No such increase was observed when the treated suspension was incubated at $0.5^{\circ}$. Untreated organisms did not increase in number when incubated in phosphate buffer, suggesting that the increase in viable number of heat-treated organisms was not due to division. The observed increase in number of viable organisms was time-dependent and complete in about $60 \mathrm{~min}$., but could be stopped by exposing the treated organisms to X-ray doses greater than $\mathrm{I} \cdot 5 \mathrm{krad}$., before or after the heat treatment. Growing the organisms in the presence of chloramphenicol $100 \mu \mathrm{g} . / \mathrm{ml}$. before heat treatment also blocked the repair mechanism, but this could be reestablished by growth in the absence of chloramphenicol for $30 \mathrm{~min}$. before heat treatment.

\section{INTRODUCTION}

The existence of a repair system in bacteria has been established and found to be of a general nature in that it operates on damage induced by various types of agents, such as X-rays, ultraviolet light, and radiomimetic agents (Setlow, I966).

Recovery in Escherichia coli cultures damaged with heat has been shown by Heinmetz, Taylor \& Lehman (1954), and the number of organisms surviving an exposure to heat found to be dependent on the use of different plating media (Busta \& Jezeski, 1963; Heather \& van der Zant, I957a, 1958), the post-incubation temperature in liquid media and the $\mathrm{pH}$ value of the plating media (Heather \& van der Zant, $1957 b$ ). In the present paper, recovery phenomenon in heated Escherichia coli populations in a medium not supporting growth has been examined.

\section{METHODS}

Escherichia coli в organisms were grown in the tris + glucose medium of Maaløe \& Hanawalt (196I). Overnight cultures were diluted 50 times with the same medium and growth continued, with aeration, at $37^{\circ}$. Rapidly growing organisms were collected by centrifugation and freed from nutrients by three washings with ice-cold $\mathrm{M}$ I 5 -phosphate buffer ( $\mathrm{pH}$ 6.9). The organisms were then suspended in warmed phosphate buffer and heated at $52^{\circ}$ in a constant temperature waterbath for various times. After the selected periods of heating the suspension was divided into three parts, one of which was placed immediately at $0.5^{\circ}$ and the others at $20^{\circ}$ and $37^{\circ}$ and held at these temperatures. The colony count of bacteria was determined at selected time intervals and the initial viable count of bacteria determined from an unheated sample. In different experiments, this concentration of bacteria varied in the range $5 \times 10^{8}$ to $8 \times 10^{8}$ 
colonies $/ \mathrm{ml}$. The number of viable bacteria was determined by plating suitable dilutions of each suspension on nutrient agar. Suspension (0. I ml.) was spread on the agar surface and the visible colonies counted after incubation at $37^{\circ}$ for $\mathrm{I} 8 \mathrm{hr}$.

The influence of X-irradiation on the recovery of heated organisms was studied by irradiating the organisms with $\mathrm{X}$-rays and then heating at $52^{\circ}$ for the required time or, alternatively, first heating at $52^{\circ}$ and then irradiating with $\mathrm{X}$-rays. The samples were then incubated at $20^{\circ}$ in phosphate buffer and the concentrations of viable bacteria determined at intervals.

$\mathrm{X}$-irradiation of the bacteria was done in the cold in a special brass holder in a small Petri dish in contact with ice from a Muller MG 150 tube run at $80 \mathrm{kV}, 9 \mathrm{~mA}$. The X-ray doses at various positions of irradiation were measured by $\mathrm{FeSO}_{4}$ dosimetry. The influence of protein synthesis on the recovery of bacteria was studied by growing organisms for $30 \mathrm{~min}$. in the presence of chloramphenicol $100 \mu \mathrm{g} . / \mathrm{ml}$. This concentration of chloramphenicol was chosen because previous experiments showed that the increase in extinction at $450 \mathrm{~m} \mu$ was completely stopped at such a concentration of chloramphenicol. After this incubation in the presence of chloramphenicol, organisms were washed free from chloramphenicol and exposed at $52^{\circ}$ for $40 \mathrm{~min}$. Subsequently, the organisms were incubated at $20^{\circ}$ in phosphate buffer. This experiment was varied by allowing growth of bacteria to occur in the absence of chloramphenicol for 20 and $30 \mathrm{~min}$. after the chloramphenicol treatment.

\section{RESULTS}

The influence of incubation at $20^{\circ}$ on the survival of heat-exposed Escherichia coli organisms is shown in Fig. 1. For convenience, the initial \% survivors in all cases was calculated to 100 . The actual number of survivors under different conditions of treatment is shown in Table I. Clearly there was an increase in the number of survivors during incubation; this increase was very steep for the first $30 \mathrm{~min}$. and reached a maximum value in about $60 \mathrm{~min}$.

When the organisms were exposed to heat for brief periods of time, the subsequent increases were small. The increase in number of survivors on incubation was greater when the number of heat survivors was small; however, an increase in number was observed in all cases. Unheated bacteria remained fully viable in control experiments under identical post-heating conditions. In all cases the maximum increase in number of survivors was reached in $60 \mathrm{~min}$. and thereafter there was no change for the rest of the $3 \mathrm{hr}$ period of the experiment. In Table I, the results of holding the heated organisms at different incubation temperatures in phosphate buffer are given. No increase in survivors was observed when heated organisms were incubated at $0.5^{\circ}$; at 37 and $20^{\circ}$ the results were similar. However, the recovery was prominent at $20^{\circ}$ for the organisms exposed to shorter periods of heating. Later experiments on the recovery were therefore done at the incubation temperature $20^{\circ}$.

The effect of inhibition of protein synthesis on the observed increase in number is shown in Fig. 2. In this experiment, the initial heat survival was $0.008 \%$ in all cases. The organisms that were exposed to chloramphenicol for $30 \mathrm{~min}$. before exposure to heat showed no subsequent increase or decrease in the number of survivors on incubation at $20^{\circ}$; but by allowing growth in the absence of chloramphenicol for 20 and $30 \mathrm{~min}$. before heat-exposure, organisms again showed the increase in survival 
number on subsequent incubation in phosphate buffer, at $20^{\circ}$. However, the increase in number was small for the organisms that were allowed to grow in the absence of chloramphenicol for only $20 \mathrm{~min}$.

Thus there was a gradual increase in number of survivors on incubation of bacteria grown in the absence of chloramphenicol for o to $30 \mathrm{~min}$. The organisms grown for

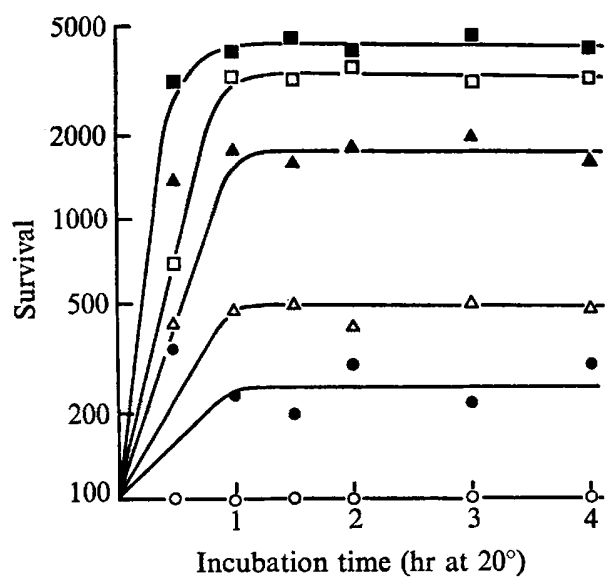

Fig. I

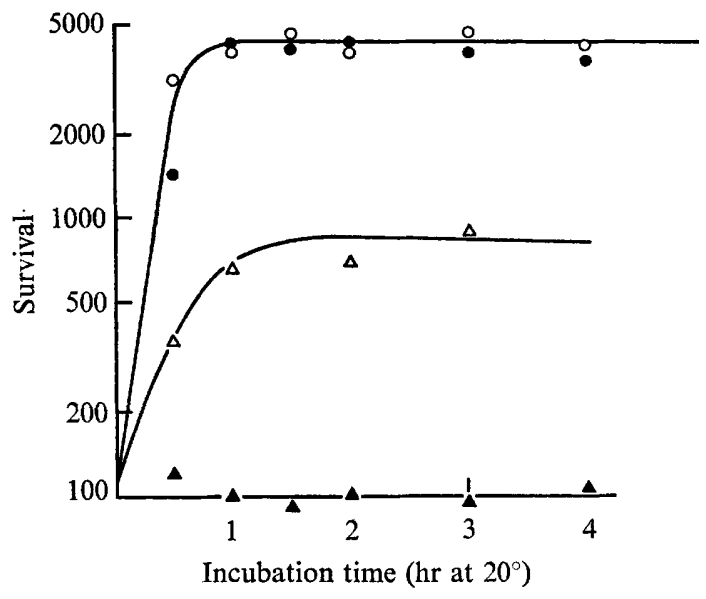

Fig. 2

Fig. I. Effect of incubation in buffer at $20^{\circ}$ on the survival of heat-damaged bacteria. Initial heat-survivors: $\mathbf{\square}, 0.008 \% ; \square, 0.01 \% ; \Delta, 0.07 \% ; \Delta, 1.4 \% ; 0,2.2 \% ; 0,100 \%$ (unheated).

Fig. 2. Influence of protein synthesis on the recovery of heat-damaged bacteria. $\bigcirc$, Protein synthesis not inhibited, prior to heating. $\Delta$, Protein synthesis inhibited by growing cells in presence of $100 \mu \mathrm{g}$. $/ \mathrm{ml}$. of chloramphenicol for $30 \mathrm{~min}$. prior to heating. $\triangle$, Protein synthesis inhibited, but prior to heating, $20 \mathrm{~min}$. of growth in absence of the inhibitor (chloramphenicol) was allowed. Protein synthesis inhibited but prior to heating $30 \mathrm{~min}$. of growth in absence of the inhibitor (chloramphenicol) was allowed.

\section{Table I. Post-incubation of heated bacteria at 0.5, 20 and $37^{\circ}$}

\begin{tabular}{|c|c|c|c|c|c|c|c|}
\hline $\begin{array}{c}\text { Temper- } \\
\text { ature of } \\
\text { post- }\end{array}$ & $\begin{array}{l}\text { Initial } \\
\text { heat }\end{array}$ & & ercentag & urviving a & incubatio & imes (hr) & \\
\hline $\operatorname{tion}\left({ }^{\circ} \mathrm{C}\right)$ & $(\%)$ & $\frac{1}{2}$ & I & $I \frac{1}{2}$ & 2 & 3 & 4 \\
\hline 0.5 & $2 \cdot 76$ & $2 \cdot 4$ & $2 \cdot 9$ & $2 \cdot 5$ & $2 \cdot 86$ & $2 \cdot 7$ & $2 \cdot 5$ \\
\hline 0.5 & 0.17 & 0.19 & 0.15 & $0 \cdot 17$ & 0.16 & 0.15 & 0.17 \\
\hline 0.5 & 0.027 & 0.026 & 0.028 & 0.027 & 0.020 & 0.027 & 0.027 \\
\hline 0.5 & 0.0015 & 0.002 & 0.0016 & 0.0016 & 0.002 & 0.0011 & 0.001 \\
\hline 20 & $2 \cdot 20$ & $7 \cdot 6$ & $5 \cdot 2$ & $4 \cdot 4$ & $6 \cdot 4$ & $4 \cdot 8$ & $6 \cdot 4$ \\
\hline 20 & $\mathrm{I} \cdot 4$ & $6 \cdot 0$ & $6 \cdot 7$ & $7 \cdot 0$ & $5 \cdot 8$ & $7 \cdot 0$ & 6.7 \\
\hline 20 & 0.07 & $I \cdot I$ & $1 \cdot 27$ & $\mathrm{I} \cdot \mathrm{I} 4$ & $I \cdot 28$ & $1 \cdot 4$ & $1 \cdot 14$ \\
\hline 20 & 0.01 & 0.07 & 0.33 & 0.316 & $0 \cdot 35$ & $0.3 \mathrm{I}$ & 0.32 \\
\hline 20 & 0.008 & 0.25 & 0.32 & $0 \cdot 37$ & 0.32 & 0.37 & 0.33 \\
\hline 37 & $\mathrm{I} \cdot 5$ & $6 \cdot 0$ & $6 \cdot 1$ & $7 \cdot 0$ & $5 \cdot 8$ & $6 \cdot 0$ & $6 \cdot 8$ \\
\hline 37 & 0.07 & 0.29 & 0.43 & 0.43 & 0.33 & 0.5 & 0.47 \\
\hline 37 & 0.015 & 0.077 & 0.12 & 0.12 & O.I I I & 0.16 & 0.12 \\
\hline 37 & 0.008 & 0.25 & 0.17 & 0.2 & 0.3 & 0.2 & 0.18 \\
\hline 0.5 & 100 & 99 & $98 \cdot 9$ & 100 & 100 & 101 & 99.5 \\
\hline 20 & 100 & 100 & 98 & $98 \cdot 8$ & $99 \cdot 2$ & 100 & 100 \\
\hline 37 & 100 & $98 \cdot 4$ & 99 & 100 & 100 & 102 & $98 \cdot 8$ \\
\hline
\end{tabular}


o min. before heat treatment showed no subsequent increase in number; organisms grown for $20 \mathrm{~min}$. showed some increase; but only the organisms grown for $30 \mathrm{~min}$. after chloramphenicol treatment showed the same increase as that given by organisms not exposed to chloramphenicol.

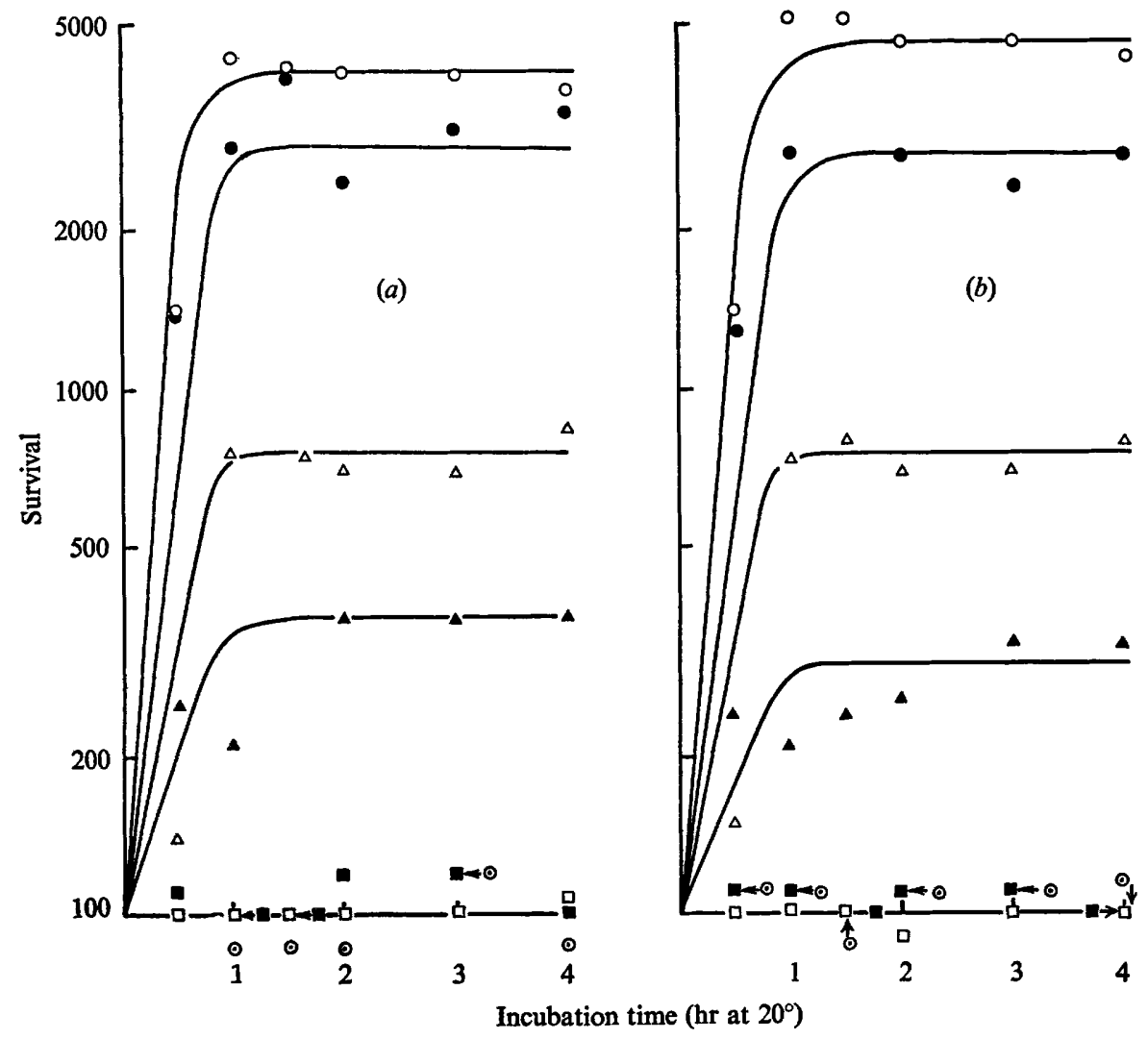

Fig. 3. Effect of X-irradiation on the recovery of heat-damaged bacteria. Curves: (a) irradiated before heating and $(b)$ irradiated after heating. Doses used; $0,0.268 \mathrm{krad}$.; $0,0.804 \mathrm{krad}$.;

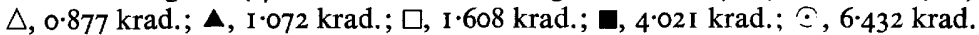

In Fig. 3, the influence of X-irradiation on the observed increase in number of survivors of heat treatment is shown. In all cases, survivors were at the level of $0.008 \%$. The organisms were exposed to various doses of X-rays either before or after the heat treatment and then they were incubated in phosphate buffer at $20^{\circ}$. Then X-irradiation affected the increase in number of heat survivors. When the X-ray doses were greater than $\mathrm{I} .5 \mathrm{krad}$., no increase was observed. This was true both for pre- and post-X-ray treatment. At X-ray doses up to $2 \mathrm{krad}$., there was a gradual suppression in the observed increase in number of post-heat survivors. 


\section{DISCUSSION}

The observed increase in number of survivors after heating at $52^{\circ}$ and incubation at 20 and $37^{\circ}$ was not likely to be due to limited division of the organisms. This follows from the fact that under identical conditions of incubation organisms not heated did not increase in number. Thus the observed increase must have been due to repair of the lesions induced by heating the organisms. In other experiments, bacteria after heating were freed from the media in which they had been heated and were incubated at 20 and $37^{\circ}$ in fresh phosphate buffer. The results obtained were identical with those in which the medium was not changed. This clearly indicated that recovery was not due to assimilation of products which leaked from the bacteria after heat treatment. However, in absolute terms, the number of organisms recovering from the damage was not high. In all cases, the observed recovery was in a medium which could not sustain growth, and in this respect the experiments presented here differ from those reported by Iandolo \& Ordal (1966). These authors made experiments in complete growth media and the observed recovery was very high; but the present experiments show that even in the absence of growth nutrients a limited amount of recovery was possible. This recovery was suppressed at $0.5^{\circ}$, indicating that some metabolism was necessary; this was further supported by the observation that growth in presence of chloramphenicol ( $100 \mu \mathrm{g}$. $/ \mathrm{ml}$.) for $30 \mathrm{~min}$. stopped the process of recovery. The recovery phenomenon was fully re-established when the organisms were subsequently allowed to grow in the absence of chloramphenicol for a period of at least $30 \mathrm{~min}$. before exposure to heating. Thus a direct involvement of protein in the mechanism is indicated. There is no evidence that chloramphenicol inhibits the synthesis of RNA (Maaløe \& Kjeldgaard, 1966). Thus even if the involvement of RNA is postulated (Iandolo \& Ordal, I966), it cannot be direct.

A feature of the repair phenomenon is that it was completely inhibited by a small dose of X-rays. This X-ray dose was of the order at which colony formation was affected. Also, whether the exposure was made before or after the heat treatment was immaterial. So it would seem that the radiation acted on a system which had the same sensitivity to radiation before and after heat treatment. Since inhibition of protein synthesis stopped the recovery process completely, it is tempting to suggest that irradiation also acts through the same pathway. However, the ultimate results of protein inhibition and of $\mathrm{X}$-irradiation were capable of suppressing the recovery. No effect on any of the synthetic abilities of cell were observed to follow these low doses of $\mathrm{X}$-rays. The division ability of heat survivors was more sensitive to radiation than that of the control bacteria. Thus the process of recovery may be unrelated to the division ability of the bacteria because, in these experiments, pre- and post-X-ray exposures had the same effect on the recovery of heat-damaged organisms. The bacteria which recovered from heat-induced lesions had the same sensitivity to $\mathrm{X}$ - and u.v.-irradiation as of untreated organisms. They also showed photo-reactivation and liquid-holding recovery, indicating that the recovered organisms were not different from the untreated bacteria in these respects.

We thank Professor N. N. Das Gupta for his interest in the work. One of the authors (P. M.) is indebted to the Ministry of Education, Government of India, for a Research Training Scholarship. 


\section{REFERENCES}

BUSTA, F. F. \& JEZESKI, J. J. (1963). Effects of sodium chloride concentration in an agar medium on growth of heat-shocked Staphylococcus aureus. Applied Microbiology II, 404.

HeATHer, C. D. \& VAN Der ZANT, W. C. (I957a). Effects of plating medium on the survival of heattreated Pseudomonas fluorescens. Food Research 22, 164.

HEATHER, C. D. \& VAN DER ZANT, W. C. $(1957 b)$. Effects of temperatureand the time of incubation and $\mathrm{pH}$ of plating medium on enumerating heat-treated psychrophilic bacteria. Journal of Dairy Science 40, 1079.

HeAtHer, C. D. \& VAN DER ZANT, W. C. (1958). Effect of metabolites on the viability of heat-treated Pseudomonas fluorescens. Food Research 23, 126.

Heinmetz, F., TAylor, W. W. \& Lehman, J. J. (1954). The use of metabolites in the restoration of the viability of heat and chemically inactivated Escherichia coli. Journal of Bacteriology 67, 5 .

IANDOLO, J. J. \& ORDAL, Z. J. (1966). Repair of thermal injury of Staphylococcus aureus. Journal of Bacteriology 9r, 134.

MaAløe, O. \& Hanawalt, P. C. (1961). Thymine deficiency and the normal DNA replication cycle. I. Journal of Molecular Biology 3, I44.

MAAløE, O. \& KJELdGAARD, N. O. (I966). Control of macromolecular synthesis, p. 16. New York \& Amsterdam: W. A. Benjamin, Inc.

SETLOW, R. B. (1966). The repair of molecular damage to DNA. In Radiation Research (G. Silini), p. 525. Amsterdam: North-Holland Publishing Company. 